\title{
The study of gas fracturing on hard coal samples using propellants
}

\section{Badanie szczelinowania gazowego na próbkach węgla kamiennego z wykorzystaniem propelantów}

\author{
Kamil Hebda ${ }^{1}$, Łukasz Habera ${ }^{1}$, Antoni Frodyma ${ }^{1}$, Piotr Koślik ${ }^{2}$ \\ ${ }^{1}$ Oil and Gas Institute - National Research Institute \\ ${ }^{2}$ Institute of Industrial Organic Chemistry, Krupski Młyn Branch
}

\begin{abstract}
The stimulation of deposits using high-energetic materials (propellants) may prove to be an effective method of acquiring methane in the coal basins of Poland. The propellants are a type of explosives which during combustion generate huge volumes of combustion gases at high pressure and temperature, and are able to impact rock structure, thus creating migration paths for methane. Until now, in the Department of Shooting Engineering of the Oil and Gas Institute - National Research Institute, a number of gas fracturing tests have been completed in laboratory scale. The experiments confirmed the ability of high-energy materials to influence the structure of hard coal. However, the setup of the laboratory rocket engine used in experiments forced the combustion products of high-energy materials to influence hard coal samples only from the front, which resulted in creating rather channels, and no model fractures in effect of the gas fracturing process. Therefore, we decided to develop an experimental setup, in which combustion products of high-energy materials would impact the rock in various directions, and create model fractures - not channels. The gas fracturing task was completed within the work on five selected coal samples that have been cored from bigger coal blocks, acquired from the KWK Zofiówka coal mine, operating on methane saturated coal beds, located in the Upper-Silesian Coal Basin in Poland. The series of experiments were performed on experimental fireground, managed by the Institute of Industrial Organic Chemistry, Krupski Młyn Branch. 100-gram charges of inhibited MPH propellant (MPH = low-diameter, heterogeneous) were used in the experiments. During the attempts of initiating propellants, pressure in the testing stand was recorded by means of a $100 \mathrm{MPa}$ pressure sensor. In order to determine the secondary fracturing grid, the hard coal samples were scanned using the CT (computer tomography) method prior to and following the tests on the experimental fireground. Next, the original and secondary fracture grid in the samples were reconstructed using specialized computer software. The analysis of the obtained results confirmed that high-energy materials are able to impact hard coal structure, causing the creation of fractures. Furthermore, the research showed that the orientation and original amount of fractures present in rocks have a very high impact on the creation of fractures in hard coal samples.
\end{abstract}

Key words: coalbed methane, gas fracturing, propellants, computer tomography, MPH solid fuel.

STRESZCZENIE: Skuteczną metodą pozyskiwania metanu w polskich zagłębiach węglowych może okazać się stymulacja złóż z wykorzystaniem materiałów wysokoenergetycznych (propelantów). Propelanty to materiały wybuchowe, które podczas spalania generują duże objętości gazów prochowych pod wysokim ciśnieniem oraz temperaturą i są w stanie wpływać na strukturę skały - tworząc drogi migracji dla metanu. Dotąd w Zakładzie Techniki Strzelniczej INiG - PIB wykonano szereg prób szczelinowania gazowego na próbkach węgla kamiennego w skali laboratoryjnej. Badania doświadczalne potwierdziły zdolność materiałów wysokoenergetycznych do wpływania na strukturę węgla kamiennego. Jednak układ laboratoryjnego silnika rakietowego wykorzystany do badań wymuszał oddziaływanie produktów spalania materiałów wysokoenergetycznych na próbki węgla kamiennego jedynie frontalne, przez co w wyniku zabiegu szczelinowania gazowego nie powstawały modelowe szczeliny, tylko kanały. Dlatego zdecydowano się opracować układ badawczy, w którym produkty spalania materiałów wysokoenergetycznych oddziaływałyby na skałę w różnych kierunkach. W pracy wykonano zabieg szczelinowania gazowego na wybranych pięciu próbkach węgla, które zostały pobrane w formie rdzenia z większych fragmentów pozyskanych z metanowej kopalni KWK Zofiówka, znajdującej się w Górnośląskim Zagłębiu Węglowym. Szereg doświadczeń przeprowadzono na poligonie doświadczalnym należącym do Instytutu Przemysłu Organicznego, Oddział w Krupskim Młynie. Do badań wykorzystano 100-gramowe ładunki inhibitowanego paliwa MPH (małogabarytowego paliwa wysokoenergetycznego). Dodatkowo podczas prób inicjacji propelantów prowadzono rejestrację ciśnienia w układzie badawczym za pomocą czujnika ciśnienia 100 MPa.

Autor do korespondencji: K. Hebda, e-mail: kamil.hebda@inig.pl

Artykuł nadesłano do Redakcji 13.02.2018 r. Zatwierdzono do druku 
W celu określenia wtórnej sieci spękań - próbki węgla kamiennego przeskanowano tomografem komputerowym przed i po próbach na poligonie doświadczalnym. Następnie zrekonstruowano pierwotną oraz wtórną sieć spękań w próbkach z wykorzystaniem specjalistycznego oprogramowania komputerowego. Analiza wyników potwierdziła, że materiały wysokoenergetyczne są w stanie wpływać na strukturę węgla, powodując tworzenie się szczelin. Ponadto badanie wykazało, że bardzo duży wpływ na powstawanie szczelin w próbkach węgla ma ich orientacja oraz ich ilość pierwotnie występująca w skale.

Słowa kluczowe: metan z pokładów węgla kamiennego, szczelinowanie gazowe, propelanty, tomografia komputerowa, MPH.

In Poland there are numerous methane deposits, accompanying hard coal beds (CBM), which according "The balance of mineral resources deposits in Poland", developed in 2017 by Polish Geological Institute - National Research Institute for Upper Silesian Coal Basin amount up to $97 \mathrm{mld} \mathrm{m}^{3}$ (Szuflicki et al., 2018). Acquiring such methane volume would advantageously influence safety of miners working in hard coal mines, as an excessive concentration of methane in a heading can endanger team of miners (Syty et al., 2017). Effective capturing of methane would additionally improve the environment, as methane is the cleanest energy source among fossil fuels (Słoczyński i Drozd, 2017). Methane production from CBM deposits would have positive influence on energy balance of the country.

The CBM deposits, considering their very low permeability, are classified as unconventional hydrocarbon deposits, requiring special developing-stimulation methods for cost-effective operation. The stimulation of coal bed methane deposits in Polish coal basins by gas fracturing with use of high-energetic materials (propellants) may prove to be an effective method of acquiring methane (Habera, 2016). The gas fracturing with propellants consists in forming several radial fractures within near-bore zone, in non-detonating manner. The fractures are created by action of propellants' combustion gases pressure that exceeds maximum stress present in rock environment.

There is a certain state of stress in the rock lying at a given depth, from which one can distinguish the minimum stresses amounting to the minimum value of rock pressure and the maximum stresses amounting to the maximum pressure of the overburden of rocks. During the gas fracturing treatment with solid fuel, a fracture is initiated after exceeding the minimum stresses. The combustion of the propellant continues, causing the pressure to build up. When the pressure exceeds the maximum stresses, a second gap perpendicular to the first is initiated. If the combustion of fuel continues and the pressure continues to increase in the rock mass, subsequent gaps occur at $30^{\circ}$ and $45^{\circ}$ angles to the main stresses (Frodyma and Habera, 2013). The described model refers to conventional hydrocarbon deposits. Scientists believe that gas fracturing can be used to exploit methane from hard coal deposits.

The research performed up to date in Department of Shooting Engineering O\&GI - NRI have demonstrated, that high energy materials are able to create net of secondary fractures in hard coal sample in laboratory scale (Hebda et al., 2018). However, during tests performed with proposed testing setup in laboratory rocket engine, frontal impact of high energy materials on hard coal sample did not result in creating model fractures, but rather channels (Fig. 1). Therefore in the research being described we decided to develop an experimental setup, in which combustion products of propellants would impact the hard coal sample in various directions and create a model fractures, not channels.
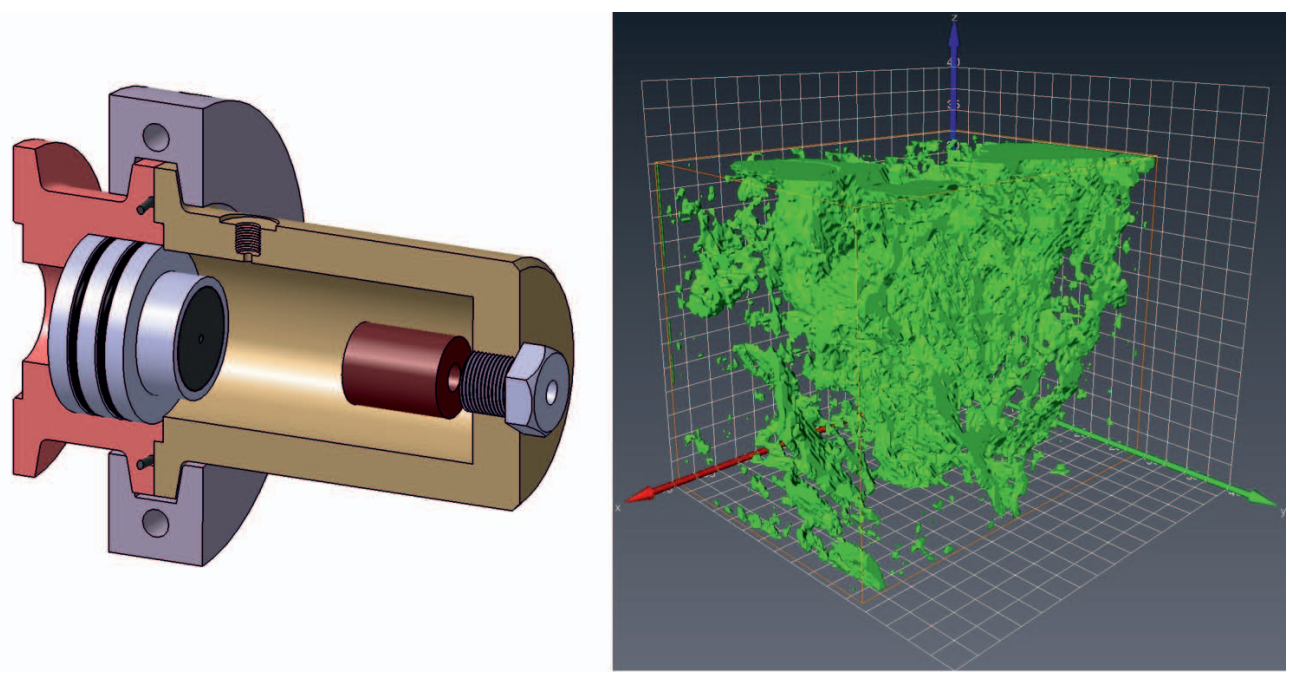

Fig. 1. The research system used in previous studies on coals, in which propellants affected the coal sample frontally, creating a network of tunnels in them. The second image shows a reconstructed 3D image of a network of cracks in a sample of coal resembling channels

Rys. 1. Układ badawczy wykorzystany w poprzednich badaniach na węglach, w którym propelanty oddziaływały na próbkę węgla frontalnie powodując powstanie w nich sieci kanałów. Drugi obraz przedstawia zrekonstruowany obraz 3D sieci spękań w próbce węgla kamiennego przypominających kanały 


\section{The experimental part}

\section{Materials}

The bigger blocks (3) of hard coal for fireground testing have been acquired from the Zofiówka methane-endangered coal mine. 5 cylinders, $200 \mathrm{~mm}$ in height and $122 \mathrm{~mm}$ diameter were cored from the coal blocks.

The small diameter high energy propellant (MPH), $100 \mathrm{~g}$ weight and inhibited with plastic was used for tests. The higher weight of high-energy material could probably destroy the testing arrangement. The high-energy propellant was ignited with pyrotechnical mass, located in igniting head.

The gas fracturing tests for 5 hard coal samples were performed on experimental fireground, managed by Institute of Industrial Organic Chemistry, Krupski Młyn Branch. Changes in the coal structure were determined from $\mathrm{CT}$ scanning results and reconstruction of tomographs, following the pressure tests.

\section{The methodology of testing}

The analyses covered pressure and temperature influence (of high-energy propellant combustion) on hard coal sample. A dedicated test arrangement was prepared for purpose of coal testing, which enabled gas fracturing of coal cylinders in various directions. The testing arrangement was composed of tubular section, blanked off from bottom side with steel lid, while special sealing plug, in which measuring instruments and electrical penetrations serving initiation of propellant were located, closed it on top. The plug was locked on the tube by means of bolts. The internals of testing arrangement was filled, from bottom side, by loose material in form of fine gravel and bigger cobbles, which filled up the free space so that coal sample and propellant were located just below the plug. A sieve, separating the loose material from coal sample and stabilizing it, while enabling free migration of combustion gases, was placed on the top of filling material. Subsequently the coal core was placed on the sieve. Between the coal core and testing arrangement walls there was $5 \mathrm{~mm}$ free space enabling action of combustion gases on coal sample and facilitating removal of the sample from testing arrangement. The whole setup was additionally filled with water, up to $90 \%$ of coal sample height, in order to minimize free space as much as possible. The measuring instrument used during tests was $100 \mathrm{MPa}$ pressure sensor, fitted in the plug, and the measurement was recorded by means of oscilloscopes (Fig. 2).

The data recorded from sensor was processed and used to create charts of pressure changes during each fracturing test and compared to each other.

In order to estimate gas fracturing effectiveness, the coal samples were CT scanned, and tomograhps obtained were processed to 3D images of fractures. The CT scanning was performed twice, prior to and after the pressure tests.
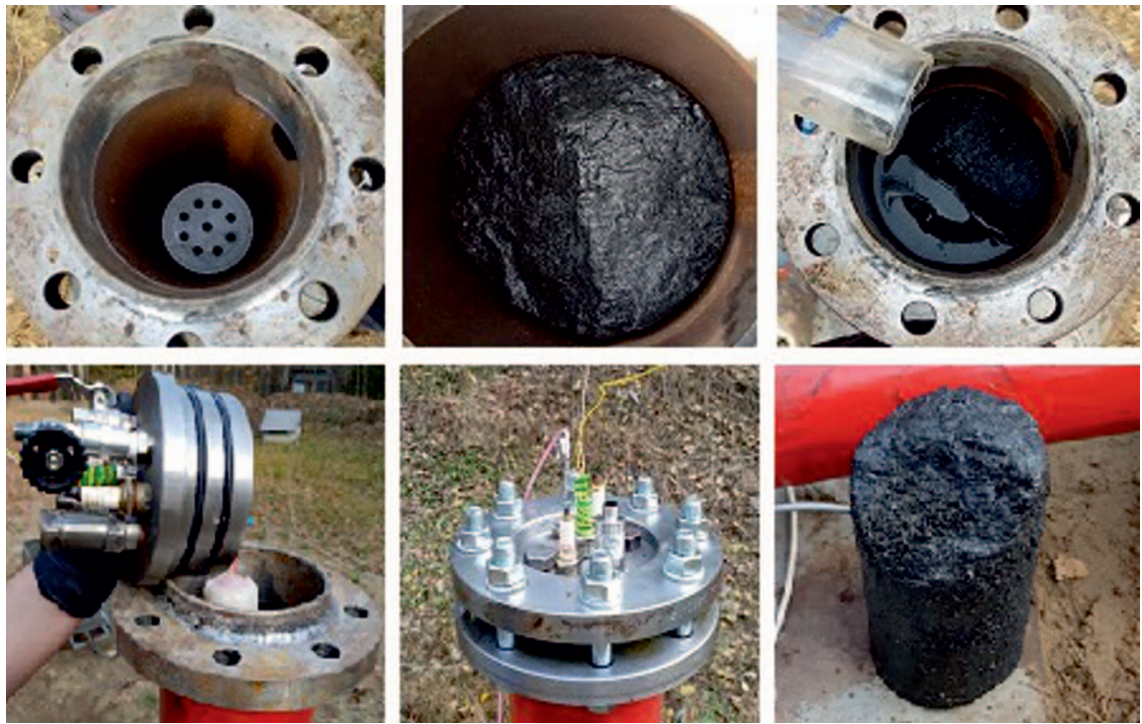

Fig. 2. Physical model of testing arrangement for gas fracturing of coal samples in laboratory scale: 1 - hard coal stabilizing steel sieve placed in the test system, 2 - coal cylinder placed on the sieve, 3 - flooding the system with water, 4 - closing lec węglowy umieszczony na sicie, 3 - zalewanie układu woda, 4 - zamykanie układu korkiem wraz z paliwem, 5 - zamknięty układ badawczy, 6 - walec węglowy po szczelinowaniu gazowym

\section{The results of tests}

The 3D and numerical reconstruction demonstrated, that pressure did no fracture the sample from the front side, where propellant were initiated, but on the edges of the sample, where it influenced fragments already existing fractures, increasing their volume or reducing their original number. This can be explained by the fact, that combusting high-energy materials generated more and more combustion gases under high pressure. The increasing pressure migrated into zones of its minimum values, that is into space between the coal sample and the wall of the testing arrangement, where it impacted hard coal sample, with still increasing value.

It has been confirmed on the grounds of reconstruction, that gas fracturing was effective in respect of 3 hard coal samples (samples 1.1, 1.2, 2.1). Combustion products of high-energy 

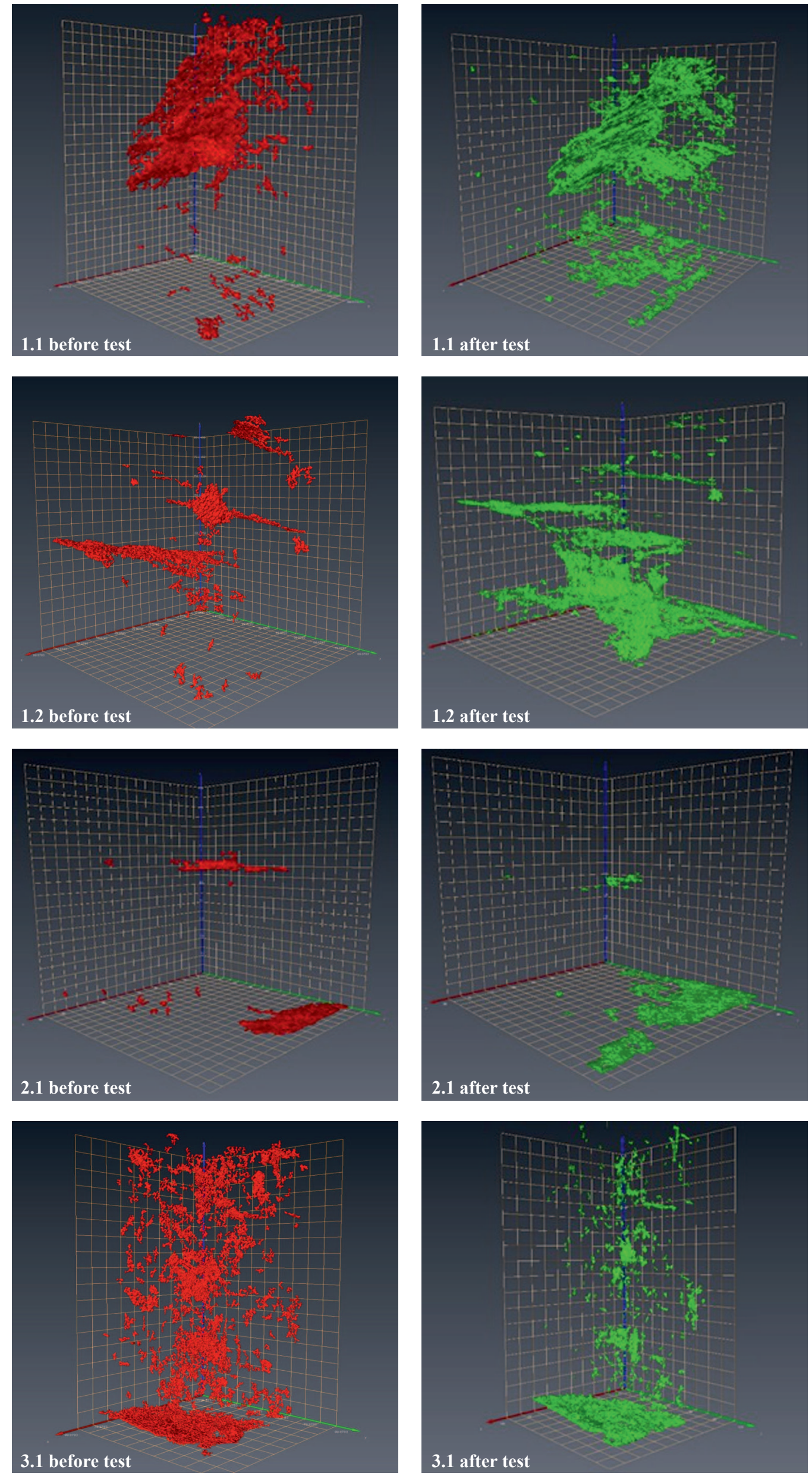


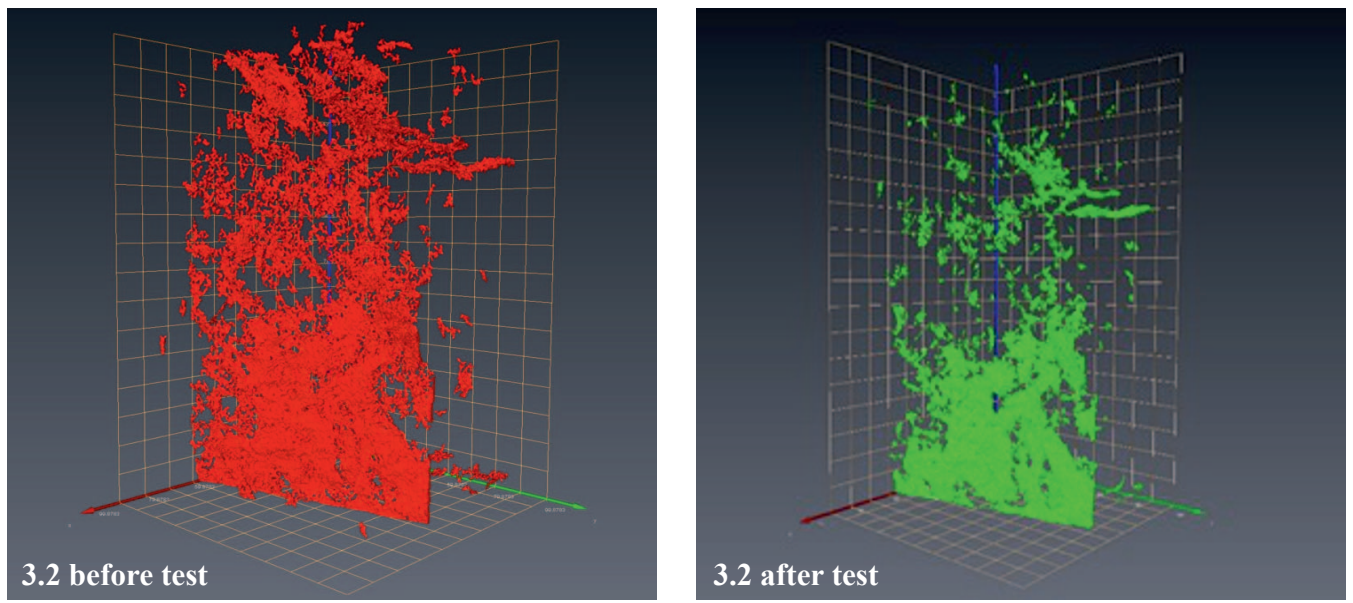

Fig. 3. Fractures network in hard coal samples prior to and after pressure tests. Images were generated in the Avizo program

Rys. 3. Sieć spękań w próbkach węgla kamiennego przed i po próbach ciśnieniowych. Obrazy zostały wygenerowane w programie Avizo

materials propagated by fractures originally existing in the coal, having orientation perpendicular to the coal cylinder wall, increasing their number.

For 2 hard coal samples (that is, 3.1,3.2) the gas fracturing was unsuccessful, and it even closed the original fractures existing in the sample. The tests demonstrated, that fractures existing in the sample, having orientation parallel to the side of coal cylinder sample, were reduced by combustion gases pressure, which reached the highest values in the space between the coal sample and the wall of testing arrangement (Fig. 4, Tab. 1).

The analysis of numerical data, obtained in effect of tomographs reconstruction, enabled us to find, that volume increase of fractures following the pressure tests was in range $33-65 \%$ as compared to fractures originally present in the coal samples. In effect of gas fracturing job for samples no. 1 and 2 the similar volume was created, while quantity of fractures created in sample no. 3 was a bit smaller, despite the identical mass of propellant was used. For 2 hard coal samples, volume of original fractures was reduced in effect of pressure tests. The reduction amounted to $56 \%$ and $43 \%$, respectively.

The maximum pressure in the system during each test ranges from 26.1 to $11.9 \mathrm{MPa}$. No relationship was observed between maximum pressure in the test arrangement and percentage changes in the structure of coal samples. Lower pressure values could be caused by compaction of loose material

Table 1. Input data after fireground tests

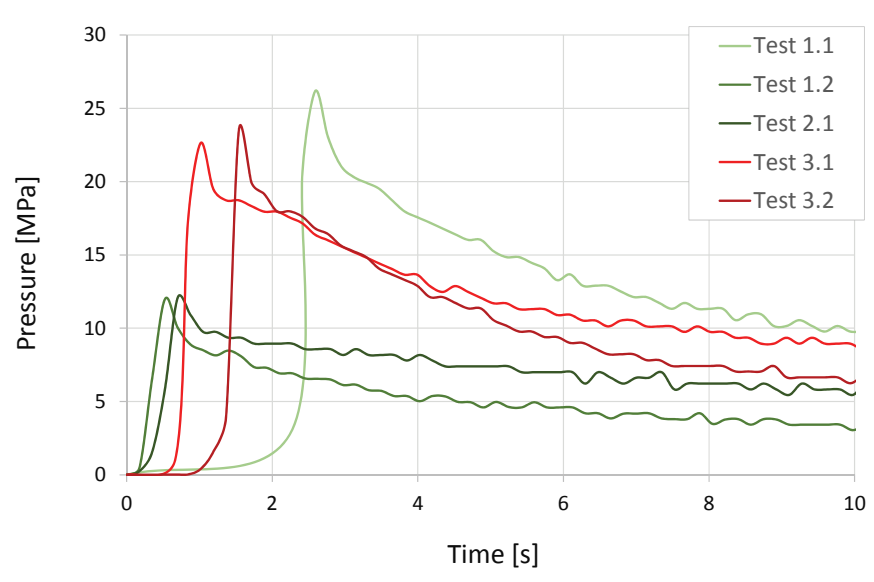

Fig. 4. Graphs of pressure changes vs. time, obtained during fireground tests. The graphs for the tests that caused the growth of gaps in the coal samples were marked in green, and the graphs for the tests in which the cracks were reduced were marked with red

Rys. 4. Zmiany ciśnienia podczas każdej z prób poligonowych. Zielonym kolorem zaznaczono wykresy dla testów, które spowodowały przyrost szczelin w próbkach węgla, a czerwonym wykresy dla testów, w których nastąpiła redukcja spękań

Tabela 1. Dane uzyskane po przeprowadzeniu testów na poligonie doświadczalnym

\begin{tabular}{|c|c|c|c|c|c|}
\hline \multirow{2}{*}{ Test No. } & $\begin{array}{c}\text { Mass of } \\
\text { propellant }\end{array}$ & $\begin{array}{c}\text { Original fracture } \\
\text { net in sample }\end{array}$ & $\begin{array}{c}\text { Secondary fracture } \\
\text { net in sample }\end{array}$ & $\begin{array}{c}\text { Increase/decrease } \\
\text { of fractures }\end{array}$ & $\begin{array}{c}\text { Maximum } \\
\text { pressure }\end{array}$ \\
\cline { 2 - 6 } & {$[\mathrm{g}]$} & {$[\%]$} & {$[\%]$} & {$[\%]$} & {$[\mathrm{MPa}]$} \\
\hline \hline 1.1 & 100 & 0.33 & 0.50 & 51 & 26.10 \\
\hline 1.2 & 100 & 0.35 & 0.58 & 65 & 11.90 \\
\hline 2.1 & 100 & 0.09 & 0.12 & 33 & 12.90 \\
\hline 3.1 & 100 & 0.57 & 0.32 & -56 & 22.60 \\
\hline 3.2 & 100 & 0.83 & 0.36 & -43 & 23.45 \\
\hline
\end{tabular}




\section{Summary and conclusions}

For purposes of testing susceptibility of coal cylinders to gas fracturing attempts in laboratory scale, dedicated stand was prepared, in which combustion products of high-energy materials will be able to impact structure of rocks under analysis. The attempts of coal fracturing proceeded with use of inhibited, small-diameter high-energy propellant, of $100 \mathrm{~g}$ mass. The pressure changes during each test on the experimental fireground was recorded by means of $100 \mathrm{MPa}$ pressure sensor.

The results of the tests indicate, that combusting highenergy materials are able to penetrate into coal structure in proposed testing arrangement. However, the effectiveness of gas fracturing depends on orientation and number of fractures originally present in the coal samples. It was demonstrated, that for 3 hard coal samples the fracturing proved to be effective and increased the volume of fractures in range from $33 \%$ up to $65 \%$. Orientation of fractures in these samples was perpendicular to the longer edge of coal cylinder, where they were impacted by combustion products of propellants having the highest pressure values. For two samples, however, the test showed reduction of fractures originally present in samples, by $43 \%$ and $56 \%$, respectively. Orientation of fractures originally existing in these samples was parallel to the longer side of coal cylinder, in result of which the pressure, of which the highest values were present on edge between the side of coal sample and wall of testing arrangement, were closing the fractures.

During the tests, pressure was also recorded. The values of maximum pressure in the system ranged between 11.9 up to 26.1 MPa. A correlation between fractures increase/reduction and maximum pressure in test system has not been found.

If the test results were to be applied to the in situ conditions in the borehole in the hard coal seam, due to the very high natural crevice of the coal, stimulation with propellants would increase the range of the existing fractures connecting them with the borehole. If there is a zone without natural system of cracks in the borehole, high-energy materials are able to create a network of fractures in the case of conventional hydrocarbon deposits. However, it is difficult to estimate the length of the fractures created in effect of the gas fracturing treatment in the coal deposit. To do this, it would be necessary to perform the simulation of high-energy materials under real conditions. The propellants during combustion generate high temperatures that create the risk of the coal ignition. However, the experience of the Department of Shooting Engineering O\&GI - NRI enables to confirm that the execution of gas fracturing within the treatment liquid environment effectively reduces the temperature of the propelant's combustion gases and the treatment liquid completely displaces free oxygen, so ignition of the coal is not likely to occur.
This paper was written on the basis of the statutory work entitled: Use of high-energy materials for hard coal fracturing in laboratory scale - the work of the Oil and Gas Institute - National Research Institute was commissioned by the Ministry of Science and Higher Education; order number: 202014/E-271/S/2018-0035, archive number: DK-4100/35/18.

\section{Literature}

Bilans zasobów złóż kopalin w Polsce wg stanu na 31.XII.2017. Warszawa: Państwowy Instytut Geologiczny - Państwowy Instytut Badawczy, 2018.

Frodyma A., Habera Ł., 2013. Zasady oddziaływań fizycznych paliw stałych w środowisku otworu wiertniczego i skał złożowych i ich implikacje dla prac stymulacyjnych. Materiały Wysokoenergetyczne, 5: 59-71.

Habera Ł., 2016. Szczelinowanie gazowe gazonośnych pokładów węgla - badania poligonowe. Nafta-Gaz, 12: 1063-1068, DOI: 10.18668/NG.2016.12.08.

Hebda K., Habera Ł., Frodyma A., Wilk Z., Koślik P., Hadzik J., 2018. Badanie charakterystyki spalania materiałów wysokoenergetycznych w laboratoryjnym silniku rakietowym przystosowanym do badań próbek węgla kamiennego. Przemyst Chemiczny, 97(7): 1064-1067. DOI: 10.15199/62.2018.7.6.

Słoczyński T., Drozd A., 2017. Metan z pokładów węgla (CBM) - doświadczenia światowe i perspektywy rozwoju w Polsce. $\mathrm{Nafta-} \mathrm{Gaz}$, 11: 851-856. DOI: 10.18668/NG.2017.11.04.

Syty J., Brodny J., Tutak M., 2017. Wentylacyjne zagrożenia skojarzone w górnictwie podziemnym węgla kamiennego. Zeszyty Naukowe Politechniki Śląskiej. Organizacja i Zarządzanie, 100: 441-456.

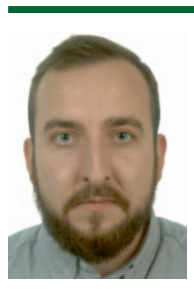

Kamil Hebda M.Sc. Eng.

Research Assistant

at the Department of Shooting Engineering

Oil and Gas Institute - National Research Institute

25 A Lubicz St.

31-503 Krakow

E-mail:kamil.hebda@inig.pl

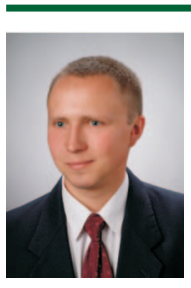

Łukasz HABERA Ph.D.

Assistant Professor

at the Department of Shooting Engineering

Oil and Gas Institute - National Research Institute

25 A Lubicz St.

31-503 Krakow

E-mail: lukasz.habera@inig.pl

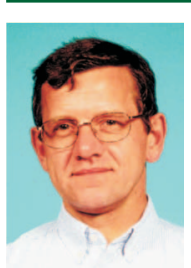

Antoni FRODYMA M.Sc. Eng.

Chief engineering- technical specialist,

Head of the Department of Shooting Engineering

Oil and Gas Institute - National Research Institute

25 A Lubicz St.

31-503 Kraków

E-mail: antoni.frodyma@inig.pl

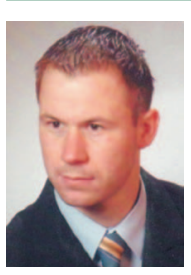

Piotr KOŚLIK M.Sc., Eng.

Research and technical specialist at the Institute of Industrial Organic Chemistry

Krupski Młyn Branch

1 Zawadzkiego St.

42-693 Krupski Młyn

E-mail: piotr.koslik@ipo.waw.pl 